\title{
Matter as a Universal: John Philoponus and Maximus the Confessor on the Eternity of the World
}

\author{
Timur Shchukin
}

National Research University Higher School of Economics, Russia tim_ibif@mail.ru

\begin{abstract}
In his Ambigua, St. Maximus the Confessor dedicated some chapters to refuting the conception of eternity of the world. That was a keystone notion for John Philoponus' system, and Maximus partly repeats his proofs in its favor and partly rejects them. The authors converge in being convinced that spatial and temporal limitations, as well as staying in motion, are unalienable features of the creation distinguishing it from the Creator. Nevertheless, in interpreting the notion of the matter they go separately, for while John Philoponus denied the existence of the matter, Maximus Confessor needed the matter concept as a cosmological basis for Christological conclusions.
\end{abstract}

\section{Keywords}

cosmology - matter - motion - eternity of the world - John Philoponus - Maximus the Confessor

John Philoponus exerted a strong influence on theological and philosophical tradition of the centuries next to his lifetime. His writings left a noticeable

* The present study is a part of a larger project Nr 16-18-10202, "History of Logical and Philosophical Ideas in Byzantine Philosophy and Theology," implemented with a financial support of the Russian Science Foundation. 
trace in Arab Monophysite and Muslim traditions as well. As for the Latin West thinkers, they learned of Philoponus both directly and indirectly from their Arab opponents. ${ }^{1}$ Nevertheless, John Philoponus should be undoubtedly considered a part of genuine Byzantine theological and philosophical studies.

The reception of John Philoponus' legacy was determined by two factors. On the one hand, he was a prominent person in the so called Alexandrian NeoPlatonist school, which was mostly focused on commenting Aristotle, the circumstance that later laid the groundwork of Latin and Byzantine interpretation of the ancient philosophical heritage (particularly in the part of terminology). On the other hand, a bad reputation of a theologian who managed to diverge in views not only with the Chalcedonite mainstream, but also with the Monophysite opposition, and came into a completely intellectual solitude by the end of his life, was permanently playing against John Philoponus. It is due to this fact that the tradition of reading and reception of John Philoponus in Byzantium appears as totally contradictory.

As a commenter of Aristotle, he was estimated by Byzantine scholars, and the works of Philoponus were copied, in particular his interpretation of Aristotle's On the Soul was in circulation. ${ }^{2}$ In spite of that, the Philoponus' treatises concerning Platonic tradition, which was clearly abandoned by Byzantines between the sixth and tenth centuries, and his 'heretic' theological writings were either scarcely documented in manuscripts or dropped from the Greek language area and were preserved only in Syrian and Arabic translations or lost at all. 3

1 On posthumous fate of John Philoponus' ideas as a whole see R. Sorabji, Philoponus and rejection Aristotelian science, Ithaca-New York, 1987; for reception in the Coptic Monophysite community, see L.S.B. MacCoull, “The historical Context of John Philoponus' De Opificio Mundi in the Culture of Byzantine-Coptic Egypt," ZAC, 9 (2006), pp. 397-423; in the Middle Age scholasticism: S. Ebbesen, "Philoponus, 'Alexander' and the origins of medieval logic," in: R. Sorabji, Aristotle Transformed, the ancient commentators and their influence, London, 1990, pp. 445-462; in the Arab-Latin tradition: M. Chase, "Philoponus' cosmology in the arabic tradition," Recherches de théologie et philosophie médiévales, 79 (2012), pp. 271-306.

2 P. Lemerle, Le premier humanisme byzantin: notes et remarques sur enseignement et culture à Byzance des origines au $X^{e}$ siècle, Paris, 1971, p. 217.

3 Almost all theological works of John Philoponus nowadays can be found in Syriac language, often only in fragments (see $C P G$ 7260-7282); the principal philosophical treatise 'On the eternity of the world against Proclus' is represented in some manuscripts, the earliest of which dates back to the IX-X centuries, and the others - not earlier than the XV century. (H. Rabe, Ioannes Philoponus. De aeternitate mundi contra Proclum, Leipzig, 1899 [repr.: Hildesheim, 1963], pp. III-XIV); another work of great importance, "On the eternity of the world against Aristotle", has also been delivered in Greek, Syriac and Arab fragments (C. Wildberg, Philoponus 
The subject of our research will be a disputation on the eternity of the world, in which John Philoponus took the most active part; therefore, it has to concern the 'platonic' part of Alexandrian thinker's legacy. Thus, we have to deal with John Philoponus as an almost forgotten and unknown thinker. But just "almost".

There could be discerned three episodes in the history of theology where the John Philoponus' "platonic" legacy in general and his teaching on the noneternity of the world is suggested to have probable influence on Byzantine authors.

The first is the controversy of Maximus the Confessor against Origenism. Within the frames of this disputation - that has had its target not only to refute the origenistic theology, but also to bring discredit to its cosmological background - Maximus could refer to the works of the great heretic, entering into polemics with them, while being under their influence. ${ }^{4}$

Secondly, the problematic field of the eternity of Universe appeared in some works of a scholar John Italos, representing the "Platonic renaissance" in the XI century. They possibly adopted some part of their argumentation against the doctrine on eternity - not excluded, in a roundabout way - from John Philoponus.

In the end, the third case refers to the name of Nicolas, the bishop of Methone and his treatise "Refutation of Proclus' Elements of theology", which

Against Aristotle, on the Eternity of the World, (Ancient Commentators on Aristotle), London, 1987, pp. 24-26)

4 It is a fact that Maximus was probably highly acquainted with John Philoponus' works, either through his supposed teacher Stephan of Alexandria (who was a disciple of John Philoponus), or by the books Maximus could access to while living in Alexandria (according to an existing suggestion that he dwelt there upon the conquest of Jerusalem by the Persians), or through Sophronius, the Patriarch of Jerusalem, his ally, who has been a friend of Stephan of Alexandria (Г.И. Беневич, "Богословско-полемические сочинения прп. Максима Исповедника и его полемика против моноэргетизма и монофелитства" in: Прп. Максим Исповедник. Богословско-полемические сочинения (Opuscula Theologica et Polemica) [G.I. Benevich, "Theological and polemical works of St. Maximus the Confessor and his controversy against Monoenergism and Monothelitism" in: St. Maximus the Confessor. Theological and polemical works (Opuscula Theologica et Polemica)], St. Petersburg, 2014, pp. 273-274). On some parallels with John Philoponus teaching on non-eternity of the world in the works of Maximus the Confessor see: T. Tollefsen, The Christocentric Cosmology of St Maximus the Confessor, OxfordNew York, 2008, pp. 42-44, 52-53, 58, 114; G.I. Benevich, "John Philoponus and Maximus the Confessor at the Crossroads of Philosophical and Theological Thought in Late Antiquity," Scr, 7-8 (2011-2012), Part I, pp. 102-130, here pp. 112-113, 118, 123-124; J. Lollar, To See into the Life of Things: The Contemplation of Nature in Maximus the Confessor's Ambigua to John, PhD dissertation, The Graduate School of the University of Notre Dame, 2011, vol. 2, pp. 342-354. 
was aimed against the tradition of John Italos. In this treatise, the theologian, inter alia, thoroughly examines the problem of the eternity / temporal nature of created being.

In this article, we've got to scrutinize the first of the mentioned cases.

In the year of 529, John Philoponus enters into a new period of his creative work. Upon a series of comments on Aristotle - dated by period between 517 and $5^{2} 6^{5}$ - he publishes a treatise "On the eternity of the world against Proclus", ${ }^{6}$ where he criticizes the views of this pagan philosopher which were circulating in Ammonius' of Alexandria school Philoponus belonged to. ${ }^{7}$ Proclus was an extremely fruitful $v$ century Neoplatonist who compiled a treatise where he promoted 18 arguments in favor of that the world never appeared and will never extinguish. John Philoponus has tied a part of his own work to each of these arguments.

The Proclus' reasons could be divided into two types:

\section{Those coming from the nature of Creator:}

1.1. The world is eternal, because God, his creative power, the divine prototype are eternal. God is ever Creator, but not at a certain period of time. That he is Creator, is always actual and never potential (I, II, III, XV, XVI, XVIII Proclus' reasons). 1.2. Everything that comes from immovable causes, is immovable in relation to his existence, although it moves and it is imperfect in this sense (IV). 1.3. If the world is created, therefore will it be destroyed? No, because God, as absolute goodness, cannot destroy the

5 Sorabji, "John Philoponus," pp. 39-40.

6 An English translation has been carried out on the basis of Rabe's critical edition: M. Share, R. Sorabji, Philoponus, Against Proclus, on the Eternity of the World 1-5, London, 2004; M. Share, R. Sorabji, Philoponus, Against Proclus, on the Eternity of the World 6-8, London, 2005; M. Share, R. Sorabji, Philoponus, Against Proclus, on the Eternity of the World 9-11, London, 2010; J. Wilberding, Philoponus, Against Proclus, on the Eternity of the World 12-18, Ithaca-New York, 2006; commented French translation of the Book 11: P. Mueller-Jourdan, Gloses et commentaire du livre XI du Contra Proclum de Jean Philopon autour de la matière première du monde, (Philosophia antiqua 125), Leiden-Boston, 2011.

7 On prehistory and background of this dicusson see: M. Chase, "Discussions on the Eternity of the World in Late Antquity," $\Sigma X O \Lambda H, ~ 5: 2$ (2011), pp. 111-173; R. Sorabji, "Waiting for Philoponus," in: Causation and Creation in Late Antiquity, eds. A. Marmodoro, B.D. Prince, Cambridge, 2015, pp. 71-93. 
world, which appears as an image of this goodness (VI, XVII). 1.4. Everything that is subject to destruction, is destroyed by its own evil. But the world is the blessed god, who does not contain any evil in himself. 1.5. Everything that is born, needs some material and a creator. And if there had been a point of time, when the world hadn't been born, either the Creator would have not possess suitable material, or he would have been inactive. But neither is possible.

2 Those coming from some eternal basis of the world, a participation in which makes the universe eternal:

2.1. The world is eternal, because if heaven co-exists with time, and time co-exists with heaven, then there's no heaven without time and no time without heaven $(\mathrm{v})$. 2.2. If the world soul is unborn and uncorrupted, then the world is unborn and uncorrupted (VII). 2.3. If something dies, it is because of an external impact. But there is nothing outside the world. Therefore, nothing can destroy the world (VIII). 2.4. The elements, which constitute the world, take their natural place, remaining in peace or moving around, and not changing in either case (X). 2.5. The matter exists for the sake of something, and therefore it is always associated with generation. However, the matter cannot appear from nothing, because in this case the generation would by accident associated with the matter, but it is impossible (XI). 2.6. A celestial body is always moving around, but not in a straight line. Therefore its motion does not imply opposites, thus the celestial body is subject to generation and corruption. Moreover, although partial things appear and corrupt, the heaven and the four elements are uncorrupted, and therefore the world, which consists of these elements, is not subject to generation and corruption.

John Philoponus disproves the first type of arguments by an assertion that no properties of Creator, such as eternity, immutability, bless and others, depend on whether a world created by God co-exists with him or not, - for the deity, the divine example and the divine action precede the world created and ordered and are irrespective of it. E. g., John Philoponus rejects the idea of "ever presence" of the world which is presumed to reflect the eternity of Creator, specifying that the infinity can not be actual, therefore, there is a limited number of things in the world, and it means that the whole of these things has its confines including those temporal. ${ }^{8}$ The reference to the eternal specimens according to which the eternal things exist doesn't not also seem correct for

8 John Philoponus, Contra Proclum, 1, 3, in: Rabe, Ioannes Pholoponus, p. 8, 1-14. 
Philoponus, because, as he suggests, the specimen precedes in being to what assimilates to it, while functioning as a creative principle. ${ }^{9}$

In refuting the second type of arguments, John Philoponus relies on a proposition that the eternity of perpetual ground is impossible to be proved, for there is no common reality beyond the physical properties of the thing, which always entail birth and collapse. For example, the reason of co-eternity of time with heaven, from which Proclus deducts the eternity of the world, is overturned by John Philoponus with a reference to that as the eternity and the time (even once the former serves as an example for the latter) are different modes of being, one would not find any necessity in that the time would co-exist with the eternity. ${ }^{10}$ While making a reference to the eternity of the world soul, Proclus states that also the cosmic body, to which the soul is conjoined, should be eternal. In response, John Philoponus reminds that even compliant to Plato, the soul is not tied to a special body, not to speak of Aristotle's viewpoint, which is known to deny the eternity of the soul. ${ }^{11}$

A dispute on the eternity of the world is also contained in the early Philoponus' comment on Aristotle's "Physics". ${ }^{12}$ In two short passages found in the third book of this comment, he is arguing with the theory of infinite time and infinite numerical continuum..$^{13}$ The treatise "Against Aristotle, On the Eternity of the World" is dedicated to the respective idea as well, and we would take into consideration the book VI for our objectives, which comprises the arguments against the eternal motion and the eternal time.

Two conclusions constitute the outcome of John Philoponus' disputation against the eternity of the world.

First, the eternity as a divine property could be perceived by what is different from the deity only as a casual (separable) attribute, inasmuch as the physical properties of a single item different from the deity are retained. Second, the emergence and the destruction as physical proprieties of a single item different from God are identical to the properties of the cosmos as it is, while any universal, different from the single things, as well as the properties of this universal, different from the denoted properties of the single things, are only intellectual constructions.

\footnotetext{
$9 \quad$ Ibid., 2, 5 in: Rabe, Ioannes Pholoponus, p. 37, 9-12.

$10 \quad$ Ibid., 5, 5 in: Rabe, Ioannes Pholoponus, pp. 118, 17-119, 10.

11 Ibid., 7, 3-4 in: Rabe, Ioannes Pholoponus, pp. 249-253.

12 H. Vitelli, Ioannis Philoponi in Aristotelis physicorum libros octo commentaria, 2 vols., (Commentaria in Aristotelem Graeca 16-17), Berlin, 1887.

13 John Philoponus, In Phys, 3, in: Vitelli, Ioannis Philoponi in Aristotelis physicorum, pp. 428, 13-430, 10; 467, 15-468, 4 .
} 
If the first conclusion could not be missed to be accepted by Byzantine intellectual tradition, in particular by Maximus the Confessor, for being a direct consequence of the Christian doctrine of creation which supposes the creature to accept the divine properties without any determination, the second was rejected by this tradition. In the points where Maximus argued with the doctrine of the eternity of the world, he simultaneously forwarded the first proposition and abandoned the second one. His conclusions from the first proposition were at least different from those of John Philoponus.

As for the issue of eternity of the world, some chapters of the tenth Ambiguum (fifth Ambiguum to John) ${ }^{14}$ are directly dedicated to them. We would not find any indication in these chapters with which aim they were written, but it's highly probable that the problems they concern are intertwined with the dispute against the Origenistic doctrine of primordial Henad and the creation of the world by the minds fallen apart from it. ${ }^{15}$ An especially discernible and consequent argumentation against this doctrine is exposed in the seventh $\mathrm{Am}$ biguum (second Ambiguum to John).

Basically, Maxim deploys his arguments from a distinction between God as absolutely immovable being and the creature which is always moving and has its origin in being created and which will once get accomplished in the One who had given it beginning, that is, in God.



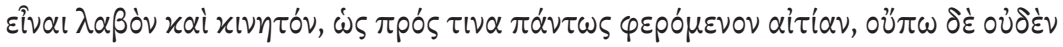

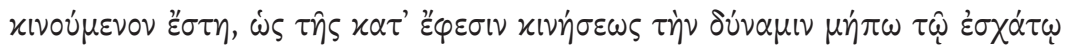

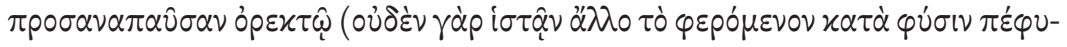

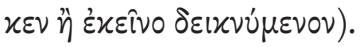

If the divine is immovable (since it fills all things), whereas everything that has received its being ex nihilo is in motion (since all things are necessarily carried along toward some cause), then nothing that moves has yet come to rest, because its capacity for appetitive motion has not yet

\footnotetext{
14 The numbering is hereinafter referred to as: N. Constas, tr. Maximus the Confessor, On Difficulties in the Church Fathers: The Ambigua, 2 vols., Cambridge, MA-London, 2014.

15 See: P. Sherwood, The Earlier Ambigua of S. Maximus the Confessor and his Refutation of Origenism, (Studia Anselmiana 36), Roma, 1955.
} 
come to repose in what it ultimately desires, for nothing but the appearance of the ultimate object of desire can bring to rest that which is carried along by the power of its own nature. ${ }^{16}$

Once the minds, according to the Origenistic thought, are immovable before the creation, that means, compliant to Maximus, its contradiction to the very nature of creature. And once they were subject to modifications while staying in eternity, that would be completely nonsense. ${ }^{17}$ In fact, the theologian assumes:



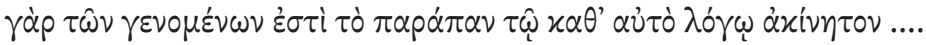

The motion is the property of created beings. The motion of intelligible beings is an intelligible motion, whereas that of sensible beings is a senseperceptible motion. None of created beings is devoid of motion according his own logos .... ${ }^{18}$

Therefore:

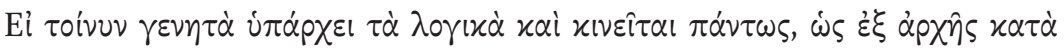

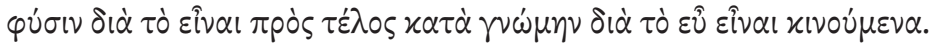

So if rational beings are created beings, then surely they are subjects to motion, since they are moved from their natural beginning in being, toward a voluntary end in well-being. ${ }^{19}$

As an alternative to the doctrine of minds fallen apart from the Henad, which, being dispersed and divided, create the world and the corporeality, Maximus promotes a conception of logoi gathered in One Logos and being indivisibly divided in an act of creation by the number of single things:

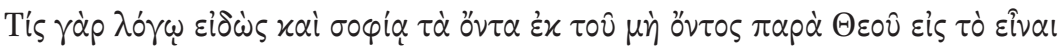

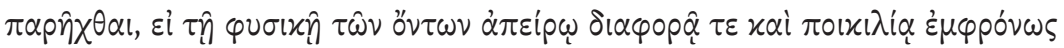

16 Maximus the Confessor, Ambigua 7, in: PG 91, col. 1069B4-11; English translation with some corrections: Constas, On Difficulties, vol. 1, p. 77.

17 Ibid., col. 1069C.

18 Ibid., col. 1072A14-1072B2; Constas, On Difficulties, vol. 1, p. 81.

19 Ibid., col. 1073C1-4; Constas, On Difficulties, vol. 1, p. 87. 


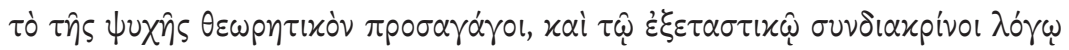



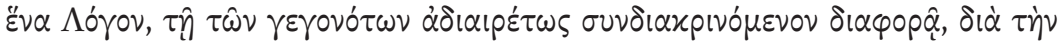

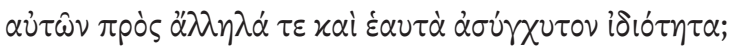

Who - knowing that it was with reason and wisdom that God brought beings into existence out of nothing - if he were carefully to direct the contemplative power of his soul to their infinite natural differences and variety, and, with the analytical power of reason, were (together with these) to distinguish in his mind the logos according to which they were created, would not, I ask, fail to know the one Logos as many logoi, indivisibly distinguished amid the differences of created things, owing to their specific individuality which remains unconfused both in themselves and with respect to one another? ${ }^{20}$

While disputing in seventh Ambiguum with the teaching on the eternity of minds, which Maximus by default regards as created, he also raises a question of eternity of the creature in general:

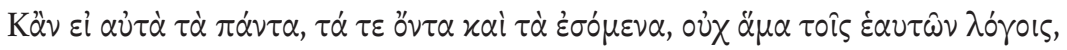

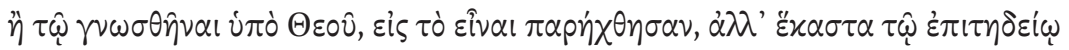

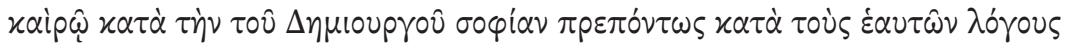

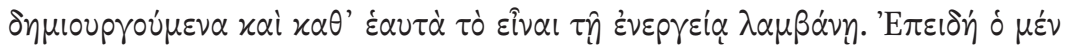

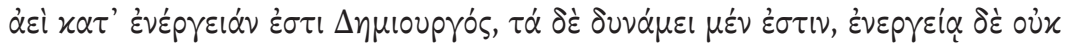

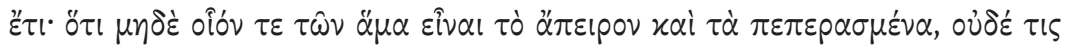

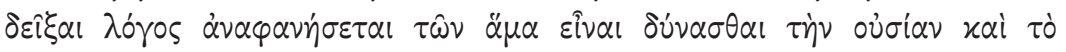

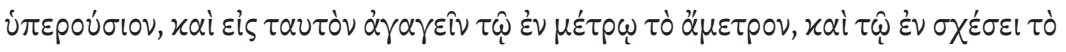

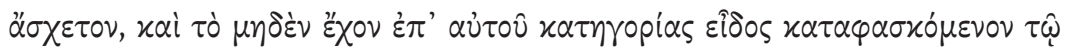

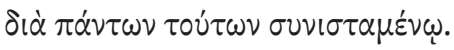

All things - both present things and things to come - were not called into existence simultaneously with their logoi or with their being known by God. Instead, in the wisdom of the Creator, individual things were created at the appropriate moment in time, in a manner consistent with their logoi, and thus they received in themselves actual existence as beings. For God is eternally an actual creator, but creatures exist first in potential, and only later in actuality; since it is not possible for the infinite and the finite to exist simultaneously. Indeed no argument will ever 
be able to demonstrate that substance and supersubstance can exist simultaneously, or that the measureless can be ranked with what is subject to measurement, or the absolute with the relative, or something of which no specific category can positively be predicated with what is constituted by all the categories. ${ }^{21}$

The key point of this excerpt is a contraposition of divine creation as unconditionally actual (or actually infinite) and created being as conditionally actual (actual finite and potentially infinite). It was actually this thesis, as seen above, that was principal for John Philoponus as well. He refuses, particularly in the third book of his treatise "Against Proclus", to deduct the absolute actuality of the world from the absolute actuality of the creative cause while referring to that the very concept of actuality, as well as that of potency, is of dualistic nature. E. g., to be experienced in grammar and to actualize this experience in something are two kinds of actuality. The ability to learn grammar and the ability to show forth what you've learned are two meanings of potency. Thus the same state, the experience in grammar could be specified as both actual and potential. God, according to John Philoponus, is a creator in the same meaning as in which a man knows grammar. He is always creator, but isn't always creating the world. ${ }^{22}$ These Philoponus' proofs should be accepted along with his doctrine on pre-existing creative logoi set forth in the second book of "Against Proclus":

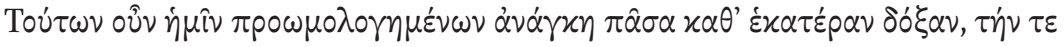

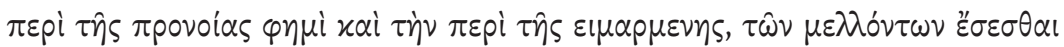

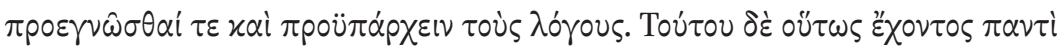

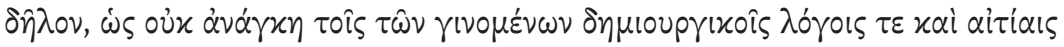

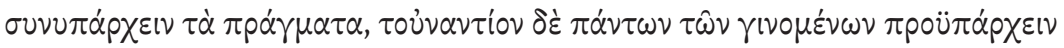

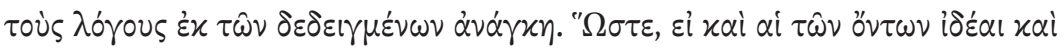

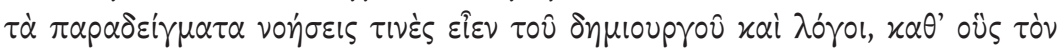

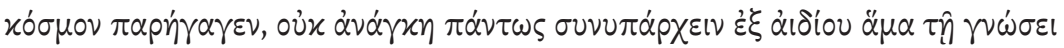

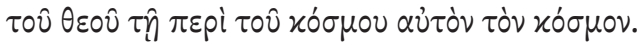

So, given that we are accepting these positions, on the basis of either doctrine - I mean the one about providence or the one about fate - there is every necessity that the principles (logoi) of future happenings should both be foreknown and pre-exist those happenings. And, this being so, it 
is clear to all that there is no necessity that the things themselves should coexist with the creative principles and causes of created things, but that it is, on the contrary, necessary from what we have shown that their principles (logoi) should preexist all created things. And so, even if the forms and patterns of things are certain concepts and principles (logoi) of the creator, in accordance with which he had brought the world into existence, it is certainly not necessary that the world itself should coexist from everlasting along with God's knowledge about the world. ${ }^{23}$

In the fourth book, John Philoponus joins these theories together reasonably pointing at that if the eternal logoi precede the creature, then there's no sense in discretion of actuality and potentiality of creation in God:

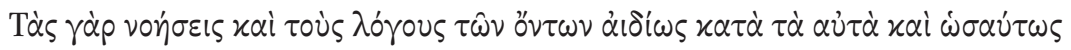



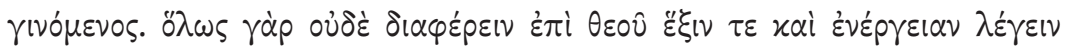

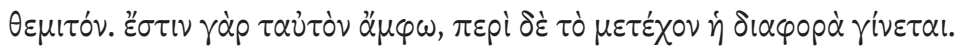

God everlastingly possesses the concepts and principles (logoi) of things, through which indeed he is a creator, in exactly the same way, and does not become different in any respect whether he produces or does not produce. For, speaking generally, it is not even proper to say that capacity and activity are different things in the case of God. The two are one and the same thing and difference arises in the sphere of that which shares. ${ }^{24}$

We are likely to deal here with the reception of doctrine on the logoi preexisting in God and creating the world by Maximus the Confessor. What is more, it is this doctrine that allows St. Maximus to discrete the eternal actuality of divine creativity and the possibility to implement this creativity in the Universe.

\section{$4 \quad$ Moderate Materialism Versus Radical Idealism}

In Ambiguum 7, the topic of the eternity of the world is not the chief one. Maximus the Confessor addresses it immediately in Ambiguum 10, where he introduces a doctrine of two types of things:

\footnotetext{
23 Ibid., 2, 5 in: Rabe, Ioannes Pholoponus, p. 41, 7-20; English translation with some corrections: Share, Sorabji, Philoponus, Against Proclus, on the Eternity of the World 1-5, pp. 41-42.

24 Ibid., 4, 9 in: Rabe, Ioannes Pholoponus, pp. 76, 26-77, 3; Share, Sorabji, Philoponus, Against Proclus, on the Eternity of the World 1-5, p. 62.
} 


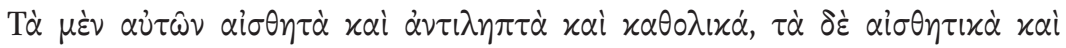

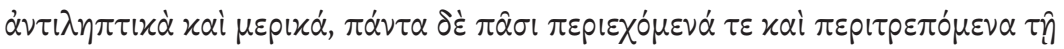

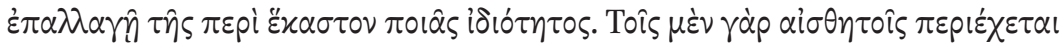

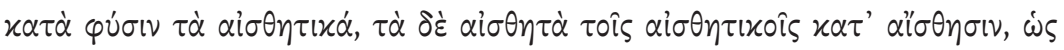

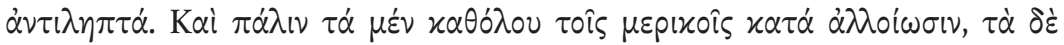

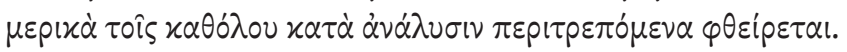

Some of these bodies are sensible, apprehensible, and universal, while others sense, apprehend, and are particular, and that all of them are contained in the others, and all of them mutate into the others by interchange of their individual properties. For beings possessing the power to sense are by nature contained among objects of sensation, while the objects are contained in sensory beings through sense perception, inasmuch as they are sensible. And, again, universals are contained by particulars through alteration, whereas particulars mutate into universals when they are destroyed by dissolution. ${ }^{25}$

There are realities which appear only as objects of cognition, and don't exist as empirical singularities, and there are singularities that reveal themselves as comprehending subjects. At the same time they penetrate and modify each other. The death of the subject is the birth of the object and vice versa. The elimination of what is able to perceive means its transformation into something that is only perceived and vice versa. The perish of general is the birth of particular and vice versa. Maximus suggests that perception, both intellectual and sensitive, is always perception of the general, not of a special thing but of a full scope of genus and species characteristics, which means that what is only cognizant, not cognizable, is singular. Hans Urs von Balthasar, interpreting this passage, speaks of a balance of contrary motions, which supports the connectedness of the universal and the partial levels of being. ${ }^{26}$ In this case it is more important for us to demonstrate that all the world is not only a set of individuals, but their living connection. Anyway, from this universal law, the finiteness of the world is concluded:



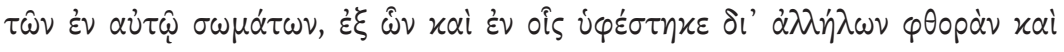

\footnotetext{
25 Maximus the Confessor, Ambigua 10.32, in: $P G$ 91, col. 1169 B9-1169C 3 ; Constas, On Difficulties, vol. 1, pp. 275, 277 .

26 H.U. von Balthasar, Cosmic Liturgy: The Universe According to Maximus the Confessor, San Francisco, 2003, pp. 159-16o.
} 


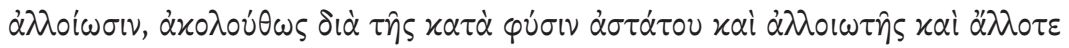

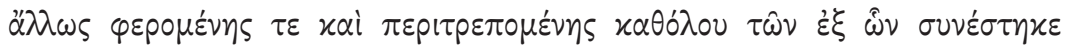

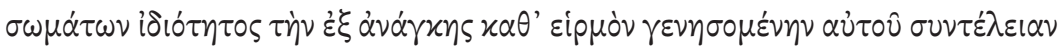

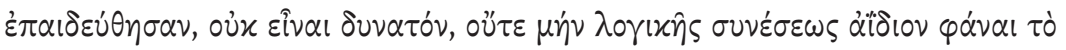

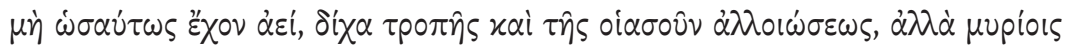

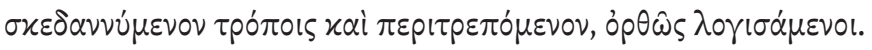

The saints, having realized that this is the constitution of the sensible world, namely, that the bodies from which and in which the world subsists are caught in a process of mutual destruction and alteration from one into the other. Consequently, the saints learned, through the natural instability and alteration and general property of bodies, from which the world subsists, to change and turn around from one to another, that the world in due sequence will necessarily come to an end, for they rightly gathered that it is neither possible, nor rationally coherent, to consider as eternal that which is not always the same, nor immune from change and alteration, but instead is scattered and changed in a myriad of ways. ${ }^{27}$

Maximus' argumentation correlates with what is given in the 11th book of the treatise "Against Proclus". Proclus proposes there a following reason: the matter ever exists in a non-accidental way but with the objective of taking some shape and, therefore, it is ever supposed to accompany a creation of something. But since the matter always exists, there is always something that needs it. ${ }^{28}$ John Philoponus objects to that, saying that there is no general matter at all:

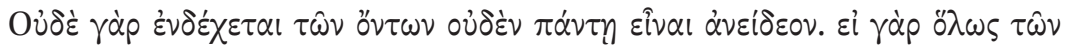

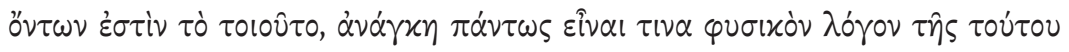

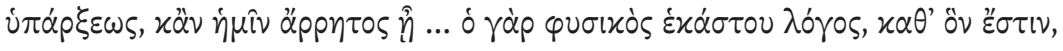

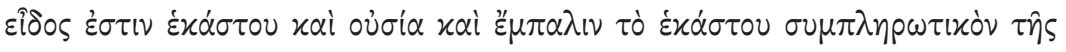

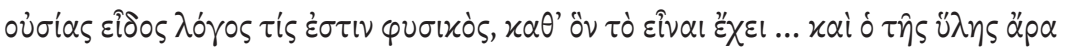

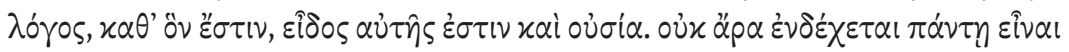

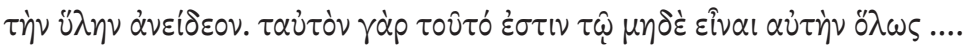

In fact, it is not even possible for anything that exists to be entirely formless. If such a thing exists at all, there must certainly be some natural

\footnotetext{
27 Maximus the Confessor, Ambigua, 10.32, in: $P G$ 91, col. 1169C1o - 1169D6; Constas, On Difficulties, vol. 1, p. 277 .

28 John Philoponus, Contra Proclum, 11, in: Rabe, Ioannes Pholoponus, p. 403, 15-17.
} 
principle of its existence, even if it is inexpressible for us ... [But it is impossible], for the natural principle of each thing in accordance with which it exists, is the form and substance of each thing, and, conversely, the form which is constitutive of the being of each thing is a certain natural principle in accordance with which it has its substance .... Therefore the principle of matter as well, in accordance with which it exists, is its form and substance. Therefore it is not possible for the matter to be entirely formless, because this is the same as its not existing at all .... ${ }^{29}$

As for the matter having form, it is presented in three-dimensional bodies, which possess no attendant qualities. They constitute the simplest level of being, ${ }^{30}$ while the most evident examples of such bodies are shapeless pieces of any material, for ex., wood. And once there's no matter beyond the corporeality, there's no reason to assert that the matter is everlasting. ${ }^{31}$

The views of John Philoponus and Maximus are close enough. Both reject the reality of isolated intelligible being, affirming that the universal is identical to the cognizable. The thinkers come into harmony in denying any permanent and identical in the thing in different modes of its being. But John Philoponus is directly naming this thing "matter", while Maximus just ascertains the absence of perpetual ontological foundation. One can see from the other chapters of Ambiguum 10 that the existence of general matter has not been doubted by Maximus the Confessor. For ex., in Ambiguum 10.39, he writes:

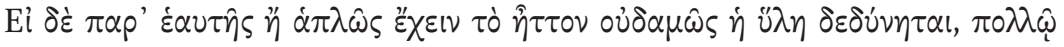

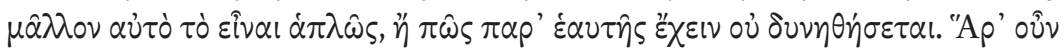

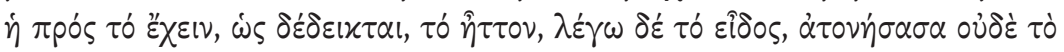

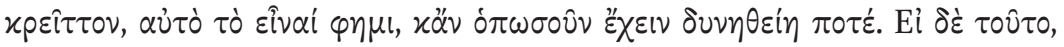

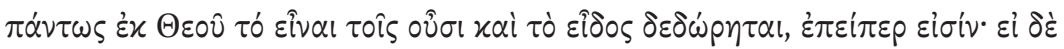

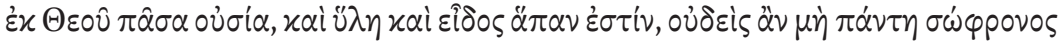

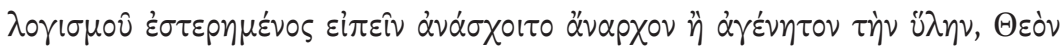

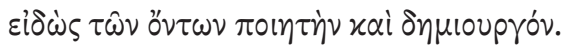

If matter can in no way possess or produce that which is inferior, still less can it possess or produce existence itself. It follows, then, that whatever is not capable of possessing the inferior, I mean form, will never be able to

\footnotetext{
29 Ibid. 11, 7 in: Rabe, Ioannes Pholoponus, p. 427, 10-428, 1; Share, Sorabji, Philoponus, Against Proclus, on the Eternity of the World 9-11, p. 81.

$30 \quad$ Ibid. 11, 7 in: Rabe, Ioannes Pholoponus, p. 428, 16-17.

$31 \quad$ Ibid. 11, 7 in: Rabe, Ioannes Pholoponus, p. 426, 13.
} 
possess what is superior, by which I mean existence itself. If this is so, then all things must have received existence and form from God, for they indeed exist. And if every substance, and matter, and form are from God, then no one, unless he has been deprived of his ability to think rationally would say that matter is without beginning and uncreated, since he knows that God has created and given form to everything. ${ }^{32}$

What is subject to modifications, Maximus believes, can not be perfect and, therefore, it needs something different to reach perfection. Hence he concludes that the matter cannot communicate any existence, that is, being to itself, for it isn't even able to communicate shape to itself, so the matter has its origin and has been created. But in this context being and being-in-form are not the same (as it is according to John Philoponus). Therefore the matter takes existence not only through the form, but also through the tertium quid of the divine act. Thus, it is important to note something other: the matter is considered as abstracted from the species, but, nevertheless, as a real substrate.

Ambiguum 10.41 is largely devoted to the matter. The principal thought of this excerpt is the definiteness and limitedness of the matter, which Maximus describes via traditional Pythagorean and Platonic notion of "dyad" - but he is interpreting this notion in a contradictory sense. ${ }^{33}$ The dyad is not put forward by him as a principle of multiplicity, limitlessness and infinite divisibility. On the contrary, it is the prime number, i. e. something that is always confined within the frame of Aristotelian logic, and that supposes a certain relationship and co-existence with something other. The dyad is a feature of creature, which differs from Creator namely in that it has limits:



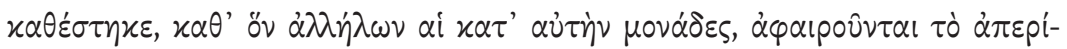

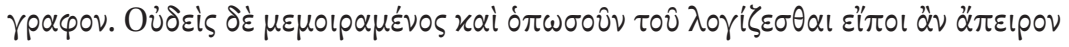

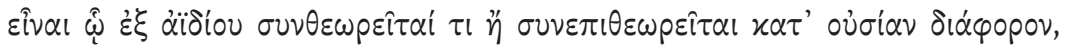

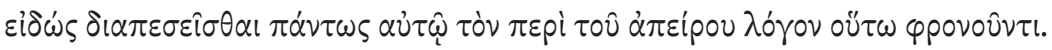

32 Maximus the Confessor, Ambigua, 10.39, in: PG 91, col. 1181D10-1184A10; Constas, On Diffculties, vol. 1, p. 299.

33 Shortly on Maximus' reception of terminology of Jamblich's "Theology of Arithmetic", which he, however, interprets hardly not in contradictory sense, see: В.В. Петров, Максим Исповедник: онтология и метод в византийской философии VII в. [V.V. Petrov Ontology and Method in Byzantine Philosophy in the Seventh Century], Moscow, 2007, pp. 98-100. 
For every dyad, and every monad that constitutes one of its parts, are constituted by number, so that the monads, which constitute the dyad, mutually impose limitation on the undefined. Now no one with any intelligence would call "infinite" something that from eternity is seen to have or be marked by some essential difference, for if he thought about it he would recognize that this falls completely outside the definition of the infinite. $^{34}$

These Maximus' thoughts, on the one hand, possibly trace back to the comments of John Philoponus on Aristotle's "Physics", where he asserts that each thing is countable, the countable can be calculated and once the number can be calculated, as different from the limited one, then no number can be limited. ${ }^{35}$ On the other hand, John Philoponus does not accept the existence of the matter abstracted of three dimensional bodies at all. It means that if there is any influence from John Philoponus, if Maximus accepts his radical Aristotelianism, which deducts a negation of any being beyond what is given as calculable from the limitedness of any number, then Maxinus reaches far more in his reasoning.

Once staying within an analogy to the doctrine of universal, it should be noted that the matter is interpreted by Maximus the Confessor - which is thoroughly in the traditional course of Byzantine thought - in the spirit of moderate realism. On the one hand, the matter actually exists and appears as a universal substrate of the created being, but it can not be contemplated while being abstracted from the singular things. Eo ipso, Maximus the Confessor just partly reproduces the logic proper to John Philoponus: the matter exists not in an intelligible way, thus the ideal three dimension bodies (the singular) don't constitute the simplest level of being. Nevertheless, the difference between Maximus the Confessor and John Philoponus can be seen most clearly in their doctrines of motion.

\section{Motion and Ultimate End}

In Ambiguum 10.36-77, Maximus the Confessor tries to adapt the argumentation of Ambiguum 7 to the proof of that the world has a beginning.

\footnotetext{
34 Maximus the Confessor, Ambigua, 10.41, in: PG 91, col. 1184D1-9; Constas, On Difficulties, vol. 1, p. 330.

35 John Philoponus, In Phys, 3 in: Vitelli, Ioannis Philoponi in Aristotelis physicorum, p. 428, 16-18.
} 


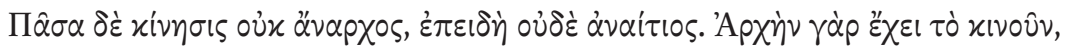

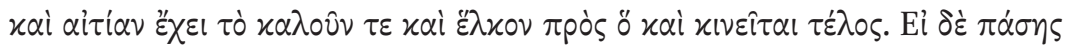

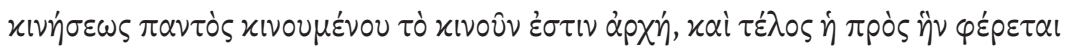

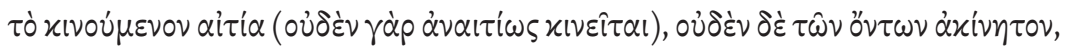

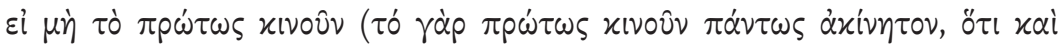



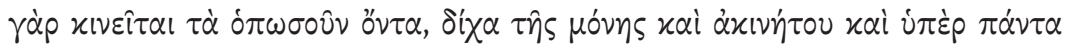

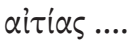

And no motion is without beginning, since it is not without a cause. For its beginning is that which set it in motion, and its cause is the end that calls it and attracts it, and toward which it is also moved. But if the mover is the beginning of every motion of everything that is moved, and if the cause toward which whatever is moved is carried along is the end (for nothing moves without a cause), then no being is unmoved, except the Prime Mover (for the Prime Mover is absolutely unmoved, since it is without beginning), from which it follows that no beings are without a beginning, since none of them is unmoved. Everything that in any way exists is in motion, except the sole, unmoved Cause that transcends all things. ${ }^{36}$

He comes to an agreement with Proclus in that the beginning of the movable and the engine is immovable Creator. However, he argues against that "everything coming from the immovable cause is immovable by its being", otherwise the God's creation is imperfect. ${ }^{37}$ Maximus the Confessor deducts the originality and finiteness of the world precisely from the mobility of the creature. The logic of universal motion is spread by the philosopher to the combination of genus and species features in that or other reality, to the changeable quality and the quantity, which lessens and augments but at the same time has a limit, as being calculable. ${ }^{38}$ In this respect Maximus follows directly Aristotle, who supposed that there is no infinite quantity: "[There could be] also no number as something separate and [at the same time] infinite: for the number, or what has number, is calculable",39 and John Philoponus himself, who denies the in-

36 Maximus the Confessor, Ambigua, 10.36, in: PG 91, col. 1177A2-14; Constas, On Difficulties, vol. 1, p. 287 .

37 John Philoponus, Contra Proclum, 4 in: Rabe, Ioannes Pholoponus, p. 55, 25-26.

38 Maximus the Confessor, Ambigua, 10.37, in: PG 91, col. 1177B-118oA.

39 Aristotle, Phys, 3.5, 204B7-8. 
finity of time on the grounds of this Aristotle's proposition..$^{40} \mathrm{John}$ Philoponus is arguing in detail on that every motion has a beginning and an end in the 6th book of the treatise "On the eternity of the world against Aristotle". He is wholly agree with the Stagirite's thesis ${ }^{41}$ of that each motion supposes the presence of the object able to perform this motion..$^{42}$ However he believes that the presence of such an object does not suppose its preexistence in time, ${ }^{43}$ therefore, its endless motion as well. John Philoponus supposes that the eternal motion is possible only if the proposition on that "nothing emerges out of nothing" is correct, ${ }^{44}$ but if it's correct in respect of natural things, it is incorrect in relation to God, who creates the form and the matter having no need in the time (fr. 115), ${ }^{45}$ and creates the motion itself, thus being a guarantor of that it does not depart into bad infinity. ${ }^{46}$ In the treatise "On the eternity of the world against Proclus", while refuting the 4-th proposition of Athenian thinker, John Philoponus emphasizes not the movability of the creature, which discerns it from Creator, but that the divine activity of God should not be subject to any description within the categories of movability / immovability and the creative act is rendered out of the "mechanisms' of created being:

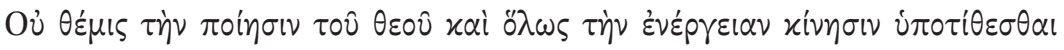

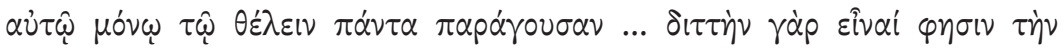

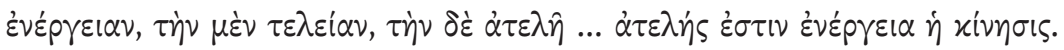

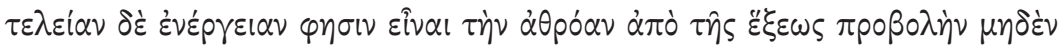

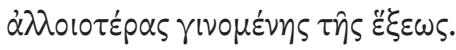

It is not right to suppose that God's producing, or his activity in general, is movement when it brings everything into existence just by willing it .... For [Aristotle] says that activity is of two kinds, complete and incomplete .... Movement is incomplete activity. By complete activity, on other hand, he means instantaneous production from a capacity without the capacity becoming in any way different. ${ }^{47}$

John Philoponus, In Phys, 3 in: Vitelli, Ioannis Philoponi in Aristotelis physicorum, pp. 428, 13-429, 10.

Aristotle, Phys, 8.1 25lAgf.

John Philoponus, Contra Aristotelem, 6, fr. 108 in: Wildberg, Philoponus Against Aristotle, pp. 123-125.

Ibid., fr. 109 in: Wildberg, Philoponus Against Aristotle, pp. 125-126.

Ibid., fr. 114 in: Wildberg, Philoponus Against Aristotle, p. 128.

Ibid., fr. 115 in: Wildberg, Philoponus Against Aristotle, pp. 128-129.

Ibid., fr. 117-120 in: Wildberg, Philoponus Against Aristotle, pp. 131-133.

John Philoponus, Contra Proclum, 4, 4 in: Rabe, Ioannes Pholoponus, p. 64, 22-65, 13; Share, Sorabji, Philoponus, Against Proclus, on the Eternity of the World 1-5, p. 55. 
And it is really this that is proper to God.

In Ambiguum 10.38, Maximus the Confessor forwards a thesis that the essential feature of created being is presence in space and time, and the very presence of these characteristics indicates at their limitedness in space and time, that is, for Maxim, the space and time are identical to a limited space and a limited time. He resumes:

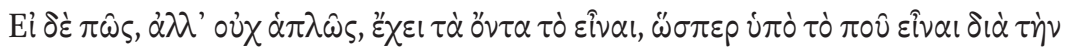

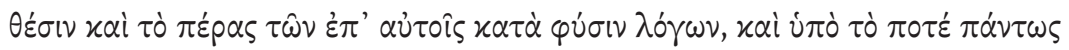

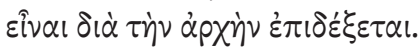

If beings have existence, not simply, but in a way qualified by a "how," then it has to be granted that, just as they exist subject to a "where," on account of the position and definiteness of their natural principles, so they are completely subject to a "when" on account of their having a beginning. ${ }^{48}$

Perhaps, Maximus doesn't simply lean on the basic concepts of Aristotle's "Physics", but on their interpretation by John Philoponus as well. Nevertheless, John Philoponus reproduces the proposition on non-infinity of time also in the treatise "Against Proclus":

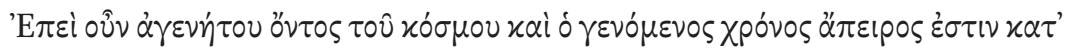

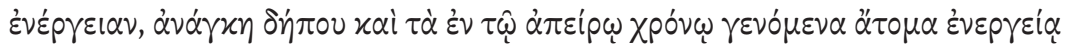

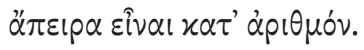

If the world is ungenerated and the time that has elapsed is also actually infinite, the individual things that have come to be in this infinite time must be actually infinite in number too. ${ }^{49}$

And this, compliant to Philoponus, is impossible by the reason of that any number is calculable.

It seems curious that if John Philoponus argues with Aristotle, while trying to prove to his supporters that the time is not infinite, Maximus the Confessor accepts this proposition as a self-evident one, that is, he looks at Aristotle with

48 Maximus the Confessor, Ambigua, 10.38, in: PG 91, col. 1180D12-1181A2; Constas, On Difficulties, vol. 1, p. 295.

49 John Philoponus, Contra Proclum, 1, 3 in: Rabe, Ioannes Pholoponus, p. 9, 14-18; Share, Sorabji, Philoponus, Against Proclus, on the Eternity of the World 1-5, p. 24. 
the eyes of John Philoponus. He starts with what John Philoponus is finishing by.

Maximus the Confessor spreads this logic in Ambiguum 10.39. He repeatedly asserts that neither essence, nor quantity, quality, relation, creation, passion, motion, feature and any other thing from the number of what the creature is sealed over by, are abolished from spatial and temporal limitedness. ${ }^{50}$ Maximus makes a stop at the temporal limitedness of the thing:

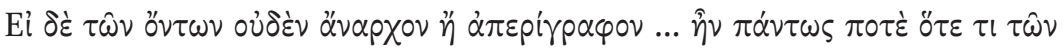

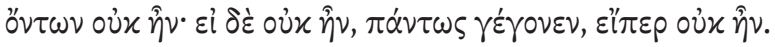

If, then, no being is without beginning or limitation ... then there was certainly a time when each being did not exist. Thus, if it did not always exist, it was brought into being at a particular time, because there was certainly a time when it was not. ${ }^{51}$

In the fifth book, John Philoponus disproves the Proclus' opinion that the very expression "there was no time" is pointing at some time in the past, therefore, at the impossibility to allow a thought of non-existence of time. John Philoponus affirms that:

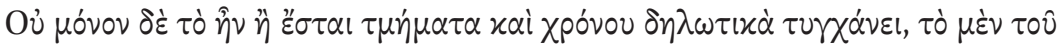

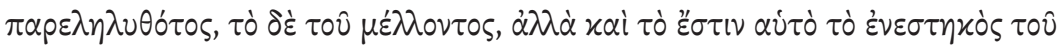

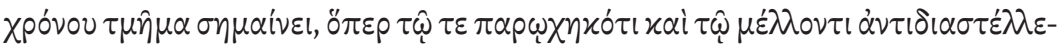
$\tau \alpha$.

And not only is it the case that 'was' and 'will be' are indicative of segments of time, the one of the past, the other of the future, but 'is' itself refers to the present segment of time, which is contrasted with both the past and the future. ${ }^{52}$

The philosopher reminds that even when we are saying "God is", we essentially use the words denoting a time segment in the present, but that does not mean that we suggest the being of God to be localized in time. ${ }^{53}$

$50 \quad$ Maximus the Confessor, Ambigua, 10.39, in: $P G$ 91, col. $1181 \mathrm{~B}$.

$51 \quad$ Ibid., col. 1181B11-1181C1; Constas, On Difficulties, vol. 1, p. 297.

$5^{2}$ John Philoponus, Contra Proclum, 5, 3 in: Rabe, Ioannes Pholoponus, p. 113, 18-21; Share, Sorabji, Philoponus, Against Proclus, on the Eternity of the World 1-5, p. 84. 
In the end, John Philoponus and Maximus the Confessor come to agreement that the motion is what distinguishes the creature from Creator, therefore, of Creator's immovability we can't make conclusion concerning creature's immovability. Both thinkers are consonant also in that it is God who is the beginning of the motion, while being beyond its limits.

\section{Key Difference}

A key difference is in that for Maximus the Confessor the general movability of the creature is not only an intelligible and abstracted feature of separate things, but also something actually existing, a "createdness" different from the thought construction, though included within the concrete creatures. For Maximus the Confessor, not the proposal on isolation of the creature within its limits, which distinguishes it from Creator, is the key one, but that the creature and dyad matter, as its principle, are in permanent motion:

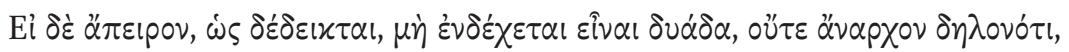

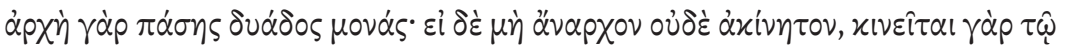

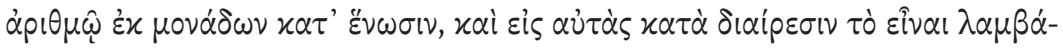

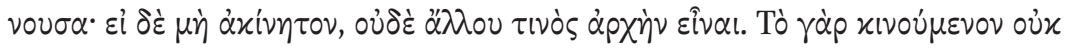

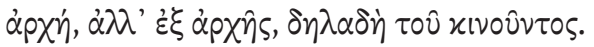

Now if, as we have demonstrated, the dyad is not infinite, it is obvious that it is not without a beginning, for the beginning of every dyad is the monad. And if it is not without a beginning, neither can it lack motion, for it moves, in fact, by means of numeration, beginning with the addition of individual monads, and then back to these again, through a process of division, and so receives its being. And if it is not unmoved, neither is it the beginning of something else. For that which is moved is not a beginning, but from a beginning, that is, from whatever set it in motion. ${ }^{54}$

Hence it follows that the matter (dyad) is not only a principle of limitedness but of mutability and movability of the creature as well, and, what is the most sufficient, of its general cohesion and relation to something other. Thus conceived, not only the matter ensures the individuality, but also the cohesion and commonality of being provide a non-intelligible unity of the nature:

54 Maximus the Confessor, Ambigua, 10.41, in: PG 91, col. 1185B1-8; Constas, On Difficulties, vol. 1, p. 305 . 


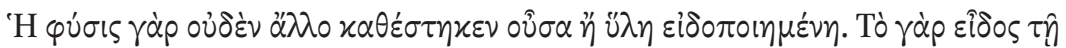

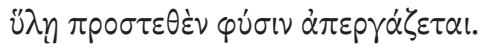

For nature is nothing other than either matter with form, or informed matter, because when form is added to matter it produces nature. ${ }^{55}$

The divergence in interpretation of the essence of the matter, as well as the disagreement in cosmology, have reflected (or, on the contrary, determined) the disagreement in Christology. Indeed, once the matter is not the prime level of being, once only the individual is real, the human nature of Christ will be individual as well - that had been John Philoponus' position, in defending which he stayed consequent. While Maximus interpreted the Incarnation of God as that of God the Word "in matter and species proper for us," 56 id est, in the common matter, confined by particular species. Eo ipso, the unity of nature in the Maximus the Confessor's theology is ensured not only through that of form, that of the whole of the world which is a consequence of the unity of creative Cause (the saint speaks of that, e. g., in the first chapter of "Mystagogy") $)^{57}$, but through the unity of the matter itself.

55 Ibid., 67, in: $P G$ 91, col. 1397A5-8; Constas, On Difficulties, vol. 2, p. 289.

$5^{6}$ Ibid., 30, in: $P G$ 91, col. 1273 C10-11.

57 Maximus the Confessor, Mystagogy, 1, in: $P G$ 91, col. 664D-665A. 